\title{
Empirical ground support and reinforcement design at Challenger Gold Mine
}

\author{
PB Hills pitt\&sherry, Australia \\ N Raymond Challenger Gold Mine, Australia \\ M Doyle Challenger Gold Mine, Australia
}

\begin{abstract}
Empirical methods form the basis of design for ground support and reinforcement of development at the Challenger Gold Mine (CGM) in South Australia. In a general sense, the rock mass conditions at CGM are very good. In situ rock stress is low relative to most Australian conditions with near hydrostatic conditions at a depth of $1,000 \mathrm{~m}$, and the rocks themselves are strong and competent.

As a consequence of the generally favourable geotechnical conditions, the design of ground support and reinforcement for mine development areas is heavily reliant on the use of empirical methods. Detailed geological and geotechnical mapping is undertaken in all headings, and particularly at the site of proposed intersections. The rock mass is characterised using the Q-System, and various techniques are used to determine the appropriate assignment of the base parameters. As an example, rock quality designation $(R Q D)$ is interpreted from three-dimensional contouring of diamond drill data and cross-checked against volumetric joint counts. Standard patterns for ground support and reinforcement are applied when the rock mass is characterised as 'good' or 'fair'. Characterisation of the rock mass as 'poor' triggers site specific design to suit the prevailing conditions. All design is augmented by kinematic wedge analysis and geological observation.

Currently, CGM ground support and reinforcement designs target a Factor of Safety (FS) of at least 1.5 in static conditions with an overriding dynamic capacity in excess of $5 \mathrm{~kJ} / \mathrm{m}^{2}$. In recent years, considerable effort has been placed on optimising the empirical designs while maintaining the overall integrity of the process. This has led to a significant reduction in use of consumables through the optimised use of geotechnical engineering.
\end{abstract}

\section{Introduction}

The CGM is located in the remote northwest of South Australia. Discovered in the 1990s, mining in the open pit commenced in 2002, underground mining commenced in 2004, and the mine has progressed from discovery to a mature operation over the past 20 years (Androvic et al. 2013). The mineralisation is contained within a complex series of sub parallel ptygmatically folded and disjointed predominantly quartz veins hosted by quartz-feldspar-garnet-biotite-cordierite gneiss of Late Archaean age within the Gawler Craton. The entire rock mass is intruded by sill-like lamprophyre dykes and a later series of near vertical ultramafic dykes.

Ground conditions at the CGM could be described as excellent. As a consequence, some early development in the upper levels of the mine was barely supported, if at all, and the consistent use of ground support and reinforcement was initially only implemented below about 460 Level. In line with current Australian practice, surface support with appropriate reinforcement is now installed in all new development over a height of $3.5 \mathrm{~m}$ above the sill. There is a clear deterioration in ground conditions with depth, but this is not alarming, nor is it a cause for concern. Even at the bottom of the mine, ground conditions could still be described as very good in a general sense. 
For the most part, ground support and reinforcement has been provided by the use of split sets and mesh as the primary support. Both black and galvanised support elements have been used in the past, although black elements were phased out in 2013 and only galvanised elements are used for primary support. The primary support is overprinted by twin strand cable bolts at all intersections, turnouts and elbows.

The purpose of this paper is to describe the empirical process by which the rock mass is characterised and the ground support and reinforcement requirements have been optimised. The approach adopted has led to a reduction in the use of consumables by up to 30 per cent in recent years.

\section{Mine datum and grid orientation}

The mine datum at CGM is Australian Height Datum $+1,000 \mathrm{~m}$ and the reduced level (RL) of the surface is approximately $1,200 \mathrm{~m}$. Levels are designated to the mine datum and thus 800 Level is approximately $400 \mathrm{~m}$ below surface, 200 Level is approximately 1,000 m below surface, and so on. CGM utilises a local mine grid which is rotated $26^{\circ}$ west of true north. These conventions apply to any reference to mine levels and orientation in this paper.

\section{$3 \quad$ Fundamental rock mass data}

Empirical design of ground support and reinforcement in an underground mine requires knowledge of the fundamental rock mass data including the material properties of the various lithologies encountered and the in situ stress conditions in which the mine is developed. The parameters utilised at CGM and described within the site ground control management plan (GCMP) are described in the following section.

\subsection{Rock material properties}

The database of rock material properties at CGM is summarised in Table 1. These properties as measured by the Western Australian School of Mines (2006) include rock mass density ( $\rho$ ), uniaxial compressive strength (UCS), Young's modulus (E), Poisson's ratio (v) and uniaxial tensile strength (UTS).

Table 1 Rock material properties at CGM

\begin{tabular}{lccccc}
\hline Rock type & $\begin{array}{c}\boldsymbol{\rho} \\
\left(\mathbf{t} / \mathbf{m}^{3}\right)\end{array}$ & $\begin{array}{c}\text { UCS } \\
(\mathbf{M P a})\end{array}$ & $\begin{array}{c}\mathbf{E} \\
(\mathbf{G P a})\end{array}$ & $\mathbf{v}$ & $\begin{array}{c}\text { UTS } \\
(\mathbf{M P a})\end{array}$ \\
\hline Granite gneiss & 2.80 & 191 & 86 & 0.24 & 13.0 \\
Ore & 2.82 & 171 & 83 & 0.26 & 14.0 \\
Mafic intrusion & 2.78 & 171 & - & - & 18.5 \\
Lamprophyre & 2.95 & 188 & - & - & 17.0 \\
\hline
\end{tabular}

\subsection{In situ rock stress}

In situ rock stress is a combination of the stress gradient increasing with depth and tectonic influences, and the orientation of the principal stresses is based on the results of in situ stress measurements undertaken by the hollow inclusion overcoring method at depths of 407, 603 and $862 \mathrm{~m}$ below surface by Mining Measurement Services $(2006 ; 2008 ; 2011)$. The principal stresses $\left(\sigma_{1,2,3}\right)$ at CGM at depth $(d)$, are as follows:

$$
\begin{aligned}
& \sigma_{1}=0.039 d-2.14 \mathrm{MPa} \\
& \sigma_{2}=0.037 d-3.37 \mathrm{MPa} \\
& \sigma_{3}=0.023 d-3.01 \mathrm{MPa}
\end{aligned}
$$

The plunge and trend of the principal stresses as illustrated in Figure 1 are as follows:

$$
\sigma_{1}=12^{\circ} / 242^{\circ}
$$




$$
\begin{aligned}
& \sigma_{2}=76^{\circ} / 094^{\circ} \\
& \sigma_{3}=07^{\circ} / 334^{\circ}
\end{aligned}
$$

where the orientation of $\sigma_{1}$ approximates the strike of the orebody, $\sigma_{2}$ is near vertical, and $\sigma_{3}$ is perpendicular to the strike of the orebody.

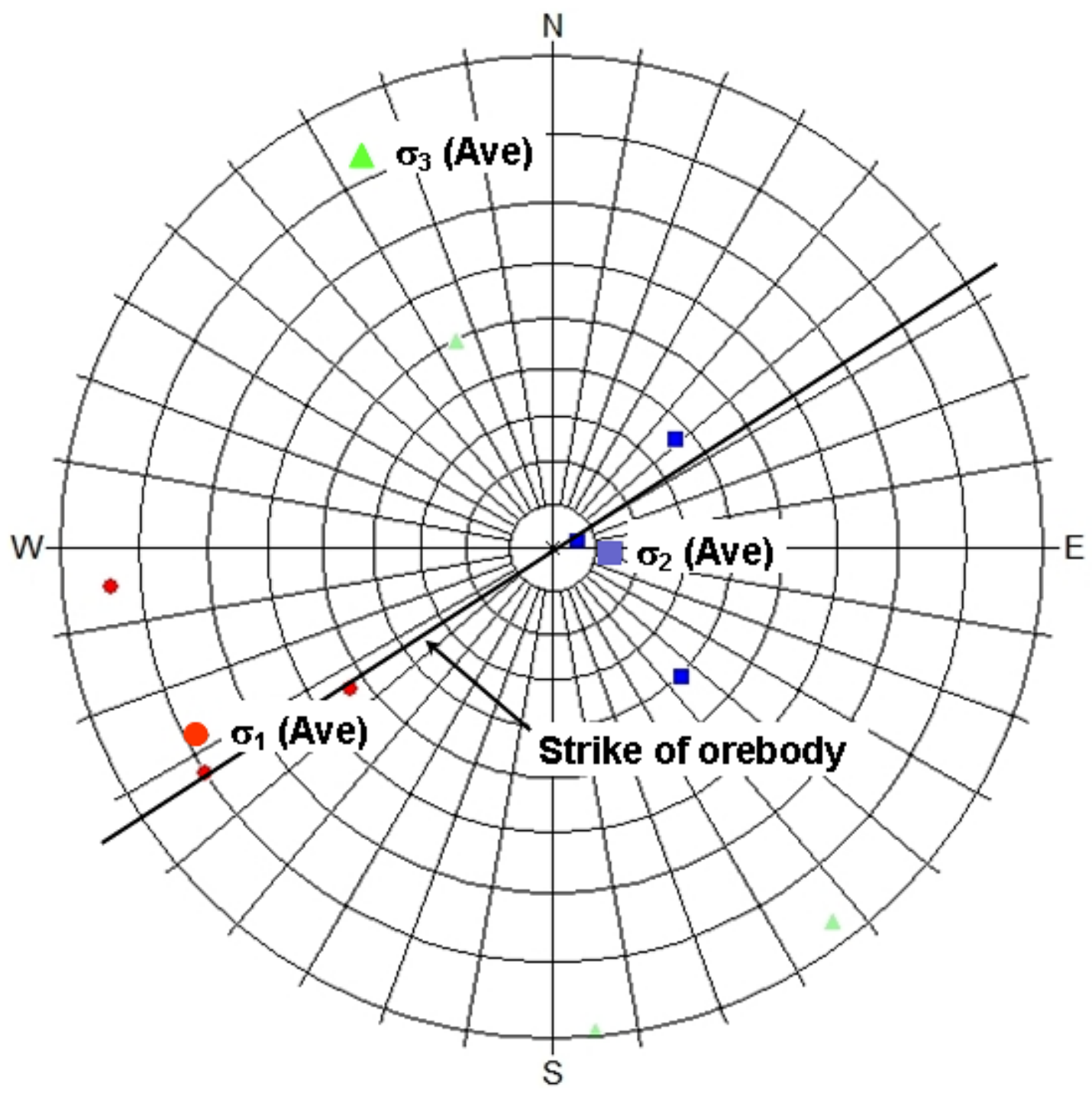

Figure 1 Stereographic representation of principal stress orientation at CGM

\section{$4 \quad$ Rock mass characterisation}

CGM utilises the Q-system of Barton et al. (1974) for characterisation of the rock mass. Q-mapping is undertaken as part of the formal geotechnical inspection at all intersections and elsewhere as necessary. Q parameters are also determined from diamond drill core. Q-mapping is used as a tool to ensure that the standard support installations are adequate, and to create a database of rock mass characteristics for the mine. This is considered adequate providing consistent results are being obtained. It is important that Q-mapping is a combination of two traverses at right angles as illustrated in Figure 2, to ensure that orientation bias does not skew the results. Both traverses are resolved in the programs Dips and Unwedge to provide a robust basis for support design on an 'as required' basis. 


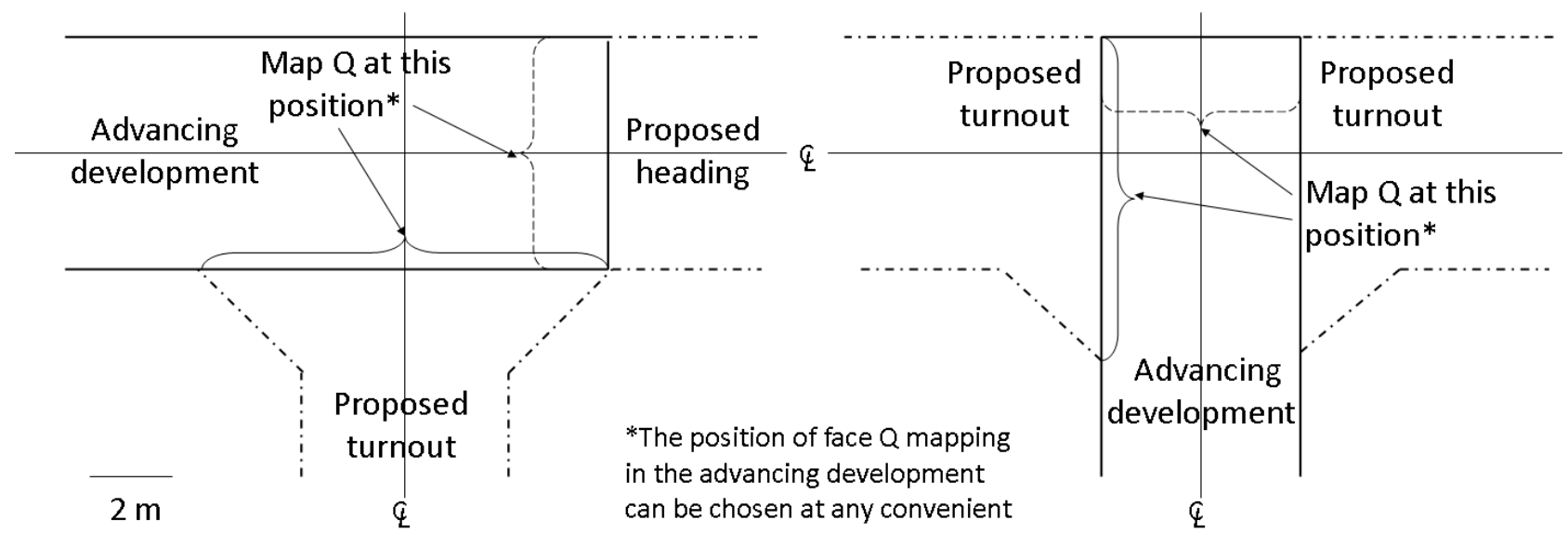

Figure 2 Timing and location of Q-mapping in the development cycle

It is a requirement for those undertaking the mapping to remain vigilant to ensure that rock mass conditions observed elsewhere on a given level are consistent with those observed at the intersections. Where that does not occur, auxiliary Q-mapping of the development occurs.

The Q-system does not require explanation. Simply,

$$
\mathrm{Q}=\mathrm{RQD} / \mathrm{Jn} \times \mathrm{Jr} / \mathrm{Ja} \times \mathrm{Jw} / \mathrm{SRF}
$$

where:

$$
\begin{aligned}
\text { RQD = } & \text { the rock quality designation as defined by Deere et al. (1967) as the proportion of the rock } \\
& \text { mass occurring in intact sections of }>10 \mathrm{~cm} . \\
\mathrm{Jn}= & \text { joint number, defined as the number of joint sets in a given location, noting that Jn is } \\
& \text { increased two-fold at portals (which in effect include stope brows), and three-fold at } \\
& \text { intersections. } \\
\mathrm{Jr}= & \text { joint roughness. } \\
\mathrm{Ja}= & \text { joint alteration. } \\
\mathrm{JW}= & \text { joint water, dependent on the level of ground water inflow, and usually set at } 1.0 \text { at CGM in } \\
& \text { dry conditions. } \\
\text { SRF = } & \text { stress reduction factor. }
\end{aligned}
$$

At CGM, RQD can be assigned from contoured RQD logging of diamond drill core, or at the face utilising the volumetric joint count (Jv) method of Palmström (1982), where:

$$
\mathrm{RQD}=115-3.3 \times \mathrm{JV}
$$

All parameters are as defined by Barton at al. (1974) and Norwegian Geophysical Institute (NGI) (2013).

Stress reduction factor (SRF) is based on the rock strength and in situ rock stress by the relationship $\sigma_{c} / \sigma_{1}$ where $\sigma_{c}$ is the uniaxial compressive strength of the intact rock and $\sigma_{1}$ is the major principal stress. As $\sigma_{1}$ varies with depth below surface, SRF also varies with depth, with a medium confining stress being the optimum condition. The SRF as determined for CGM is based on available rock mass parameters and stress measurements using a nomogram prepared by Kirsten (1983), copied here as Figure 3 (after Hutchison \& Diederichs 1996). 


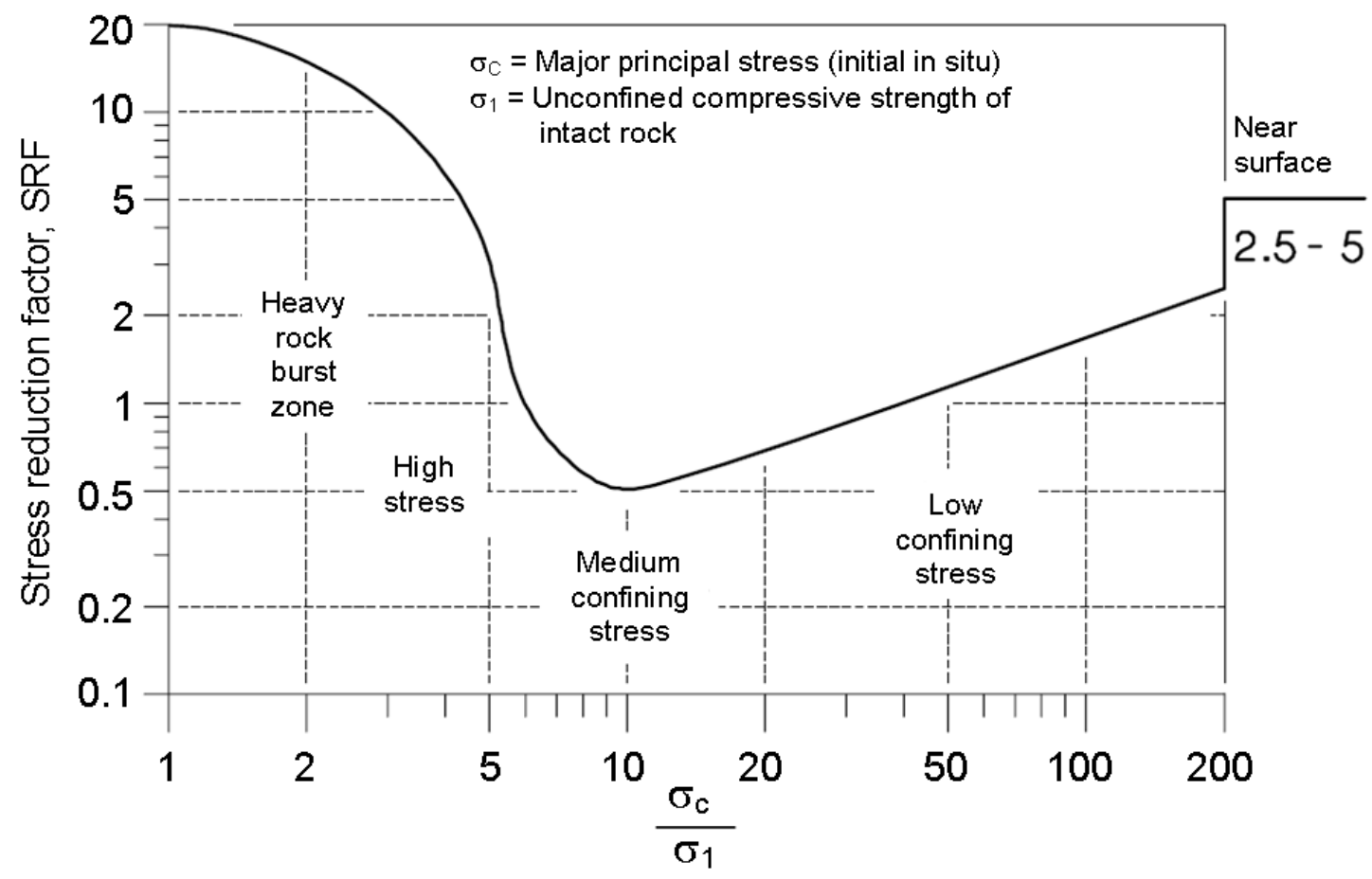

Figure 3 Nomogram for the determination of SRF

Using the nomogram and rock strength and stress data as reported in the GCMP, Table 2 illustrates $\sigma_{c} / \sigma_{1}$ and corresponding SRF for CGM.

Table 2 Determination of SRF for CGM

\begin{tabular}{c|cccc}
\hline RL & $\sigma_{c} / \sigma_{1}$ & SRF & $\begin{array}{c}\text { SRF } \\
\text { (intrusives) }\end{array}$ & $\begin{array}{c}\text { SRF } \\
\text { (shears) }\end{array}$ \\
\hline $1129-1090$ & 103.9 & 1.2 & 2 & 2.5 \\
$1089-1070$ & 56.2 & 1.1 & 2 & 2.5 \\
$1069-1050$ & 43.0 & 1 & 2 & 2.5 \\
$1049-970$ & 27.1 & 0.8 & 2 & 2.5 \\
$969-850$ & 15.6 & 0.7 & 2 & 2.5 \\
$849-710$ & 10.1 & 0.6 & 2 & 2.5 \\
$709-530$ & 7.0 & 0.5 & 2 & 2.5 \\
$529-430$ & 5.5 & 0.6 & 2 & 2.5 \\
$429-370$ & 4.9 & 0.7 & 2 & 2.5 \\
$369-350$ & 4.7 & 0.8 & 2 & 2.5 \\
$349-290$ & 4.4 & 0.9 & 2 & 2.5 \\
$289-190$ & 4.1 & 1 & 2 & 2.5 \\
$189-090$ & 3.7 & 2.9 & 3 & 3.4 \\
$089--10$ & 3.3 & 4.5 & 4 & 4.2 \\
$-11--110$ & 3.0 & 5 & 5 & 5.0 \\
\hline
\end{tabular}




\section{$5 \quad$ CGM Q-Chart}

The Q-Chart has evolved since it was first devised by Barton et al. (1974). Figure 4 illustrates the general range of CGM Q data on the latest version of the Q-Chart (NGI 2013). Throughout its history, the Q-Chart has plotted $Q$ against the quotient span/excavation support ratio (ESR). That quotient is the equivalent dimension (De) and an ESR of 1.6 (assigned to permanent mine openings). For typical development the equivalent dimension:

$$
\mathrm{De}=\text { span } / \mathrm{ESR}=3.75,3.4 \text { or } 3.1 \text { for } 6.0,5.5 \text { or } 5.0 \mathrm{~m} \text { wide development respectively }
$$

For a typical range of $Q$ where:

$$
Q=4 \rightarrow>10
$$

On the basis of the Q-Chart, ground at CGM plots in an area indicating a bolt spacing of $1.6-2.0 \mathrm{~m}$ utilising bolts and no shotcrete. A maximum width of development at $6.0 \mathrm{~m}$ is established, at which point the support requirement crosses the shotcrete threshold for $Q=4$.

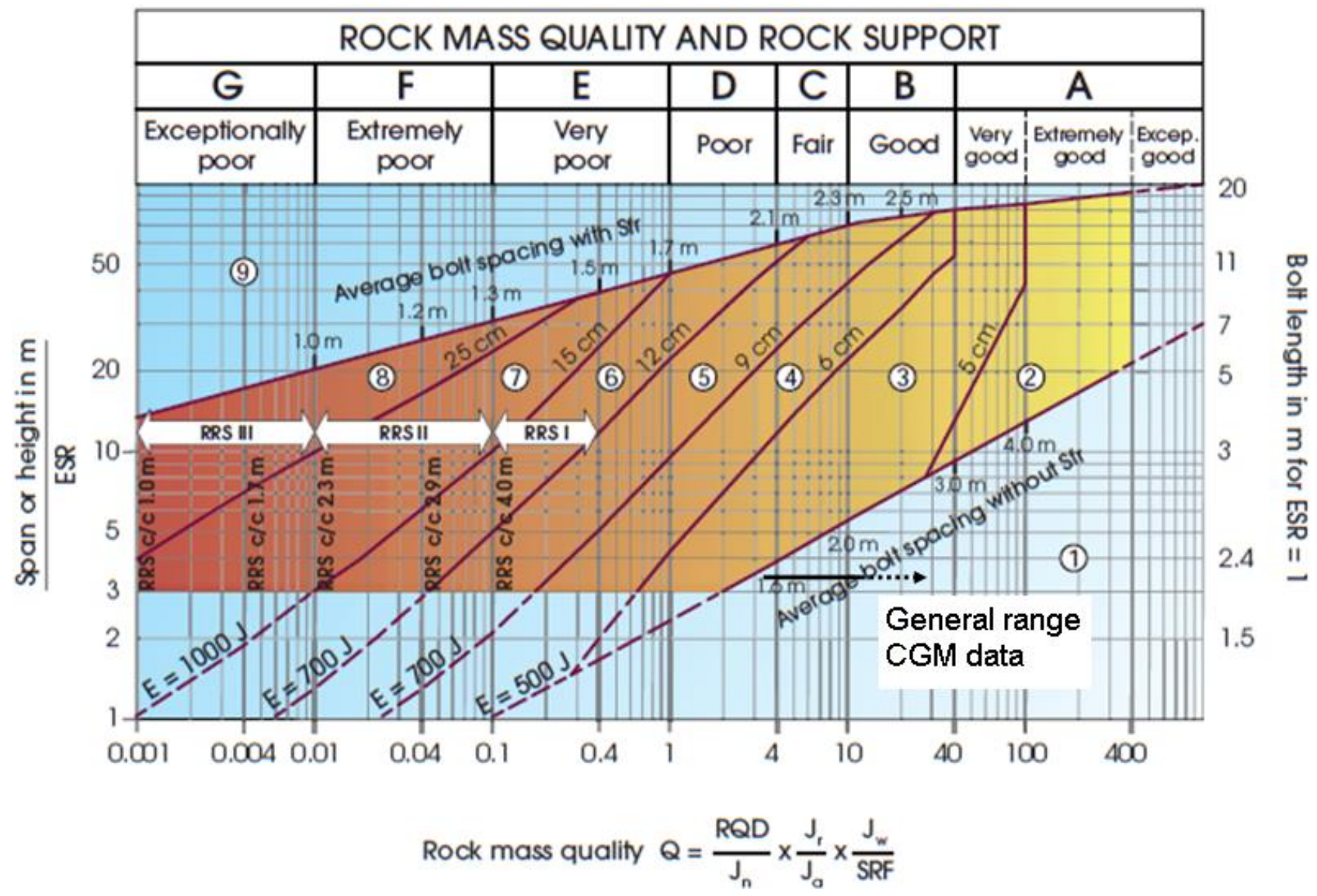

Figure 4 Q-Chart (NGI, 2013) illustrating the general range for CGM data

\section{Standard ground support and reinforcement elements}

\subsection{Mesh}

Although the Q-Chart suggests that spot bolting without surface support is adequate, such a ground support and reinforcement regime is not consistent with best practice in Australia. Bolt spacing is dictated by the lesser of two empirical dimensions; the bolt spacing as defined by the Q-Chart, and the bolt spacing necessary to support the surface support. Standard support designs are based on the use of $2.4 \mathrm{~m}$ split sets and $5 \mathrm{~mm}$ galvanised mesh sheet with a $100 \mathrm{~mm}$ square pattern. The mesh sheet size at CGM is $4.5 \times 2.4 \mathrm{~m}$ 
and dictates the use of a maximum $1.1 \times 1.4 \mathrm{~m}$ bolt spacing as illustrated in Figure 5 . The mesh overlap is managed with $0.9 \mathrm{~m}$ mesh pins installed inside the last row of $2.4 \mathrm{~m}$ split sets from the previous sheet.

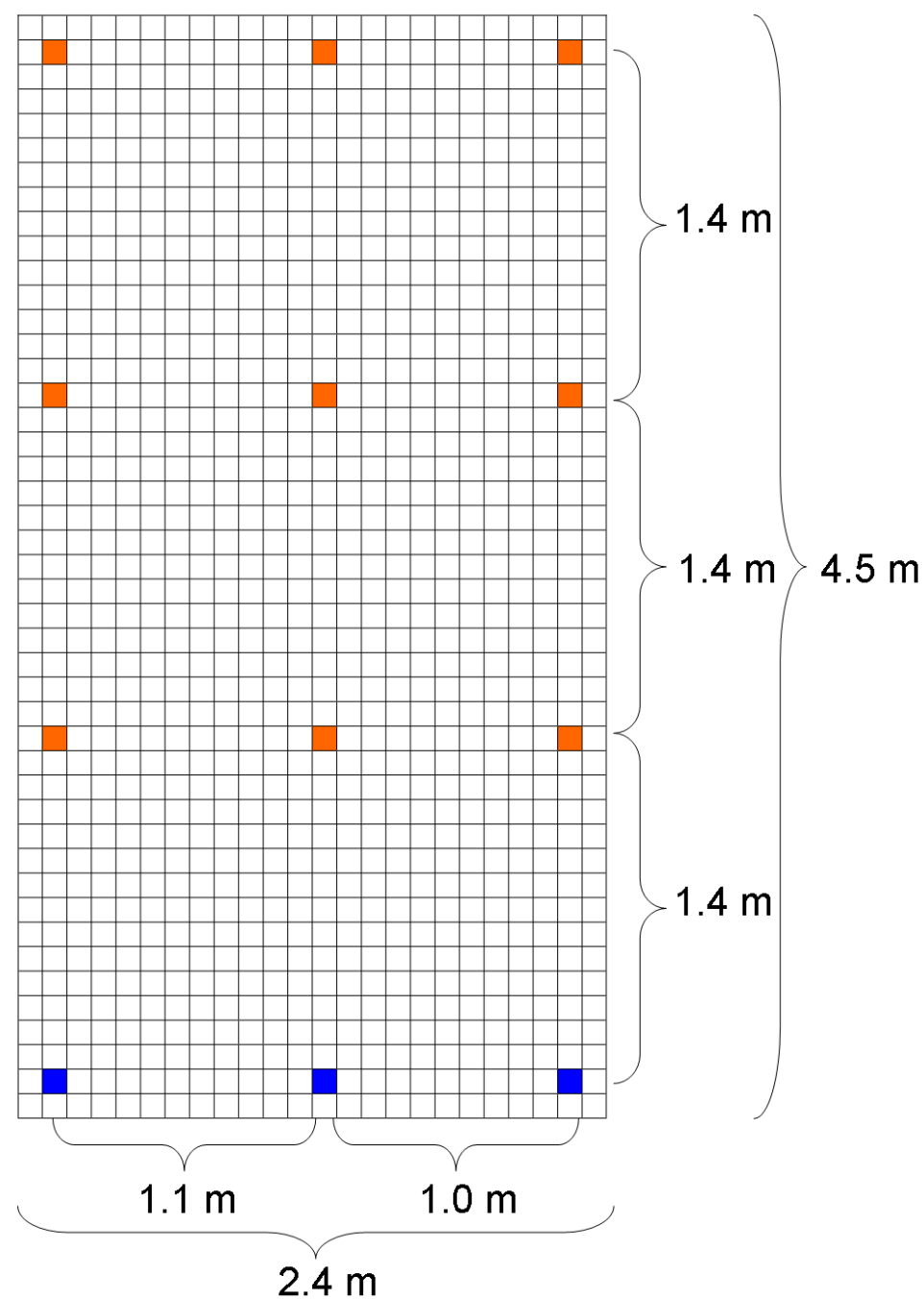

Figure 5 The mesh size used at CGM illustrating the maximum bolt spacing

\subsection{Split sets}

Standard $2.4 \times 46 \mathrm{~mm}$ split set friction anchors are the standard bolt used at CGM. Manufacturer expectations are that such bolts have a load capacity of $4-5 \mathrm{t} / \mathrm{m}$, which is in line with published results (Kaiser et al. 1996). Allowing $0.1 \mathrm{~m}$ for the toe taper, the bolts have an effective embedment length of $2.3 \mathrm{~m}$ and an expected design capacity of 9.2-11.5 $\mathrm{t}$. The results of pull-testing programs undertaken at CGM suggest that this capacity is achieved in the vast majority of cases.

Equations for the empirical determination of bolt length have been proposed by Pender et al. (1963), Shach et al. (1979), and Barton et al. (1980) respectively as follows:

$$
\begin{gathered}
L=1.8+0.013 \times B^{2}=2.26 \mathrm{~m} \\
L=1.4+0.36 \times(B / 2)=2.48 \mathrm{~m} \\
L=(2+0.15 B) / E S R=1.81 \mathrm{~m} \text { for a } 6.0 \mathrm{~m} \text { wide excavation }
\end{gathered}
$$

where $B$ is excavation width and ESR is the excavation support ratio having the definition of Barton et al. (1974). On balance, $2.4 \mathrm{~m}$ split set friction anchors with an effective length of $2.3 \mathrm{~m}$ are considered adequate at the increased density required by the mesh and in consideration of the empirical depth of fracture surrounding development openings discussed in Section 6.3, for development up to $6.0 \mathrm{~m}$ wide. 


\subsection{Ground support and reinforcement minimum requirements}

Standard profiles for support of development based on excavation size were devised for development:

- $4.0 \mathrm{~m}$ wide $\times 4.5 \mathrm{~m}$ high.

- $4.5 \mathrm{~m}$ wide $\times 5.0 \mathrm{~m}$ high.

- $5.0 \mathrm{~m}$ wide $\times 5.0 \mathrm{~m}$ high.

- $5.5 \mathrm{~m}$ wide $\times 5.8 \mathrm{~m}$ high.

For good and fair ground conditions on the basis:

- Good ground $Q \geq 10$.

- Fair ground $10>Q \geq 4$.

- Poor ground $\mathrm{Q}<4$.

Standard profiles have the following design characteristics:

- Mesh $2.4 \mathrm{~m}$ wide to be oriented along the development.

- Each mesh sheet to be secured by three $2.4 \mathrm{~m}$ split sets in each ring.

- Split sets are to be situated at least one full mesh square from the edge of the sheet in all directions.

- In line with accepted good practice in Australia, based on the legislated requirement applying in Western Australia, mesh is extended to a maximum height of $3.5 \mathrm{~m}$ above the sill regardless of ground conditions.

For good ground conditions, spot bolting is recommended below the mesh. The amount of spot bolting may vary due to local conditions and is determined on a case by case basis. However, in line with the $\mathrm{Q}$-Chart recommendations, the spot bolt spacing does not exceed a $2 \times 2 \mathrm{~m}$ pattern, given typical $\mathrm{Q}$ values in good ground at CGM. For fair ground conditions, mesh is extended to the grade line with the requirement that it is not more than $1.8 \mathrm{~m}$ above the sill. Ground support and reinforcement in poor ground conditions is site specific. Individual designs will at least match those applying in fair ground, but in addition may require a tighter split set pattern or site specific cable bolt design. Kinematic wedge analysis using site specific geotechnical data and analysis using the program Unwedge always forms part of the design process in poor ground. Examples of standard profiles in good and fair ground conditions are illustrated in Figure 6.

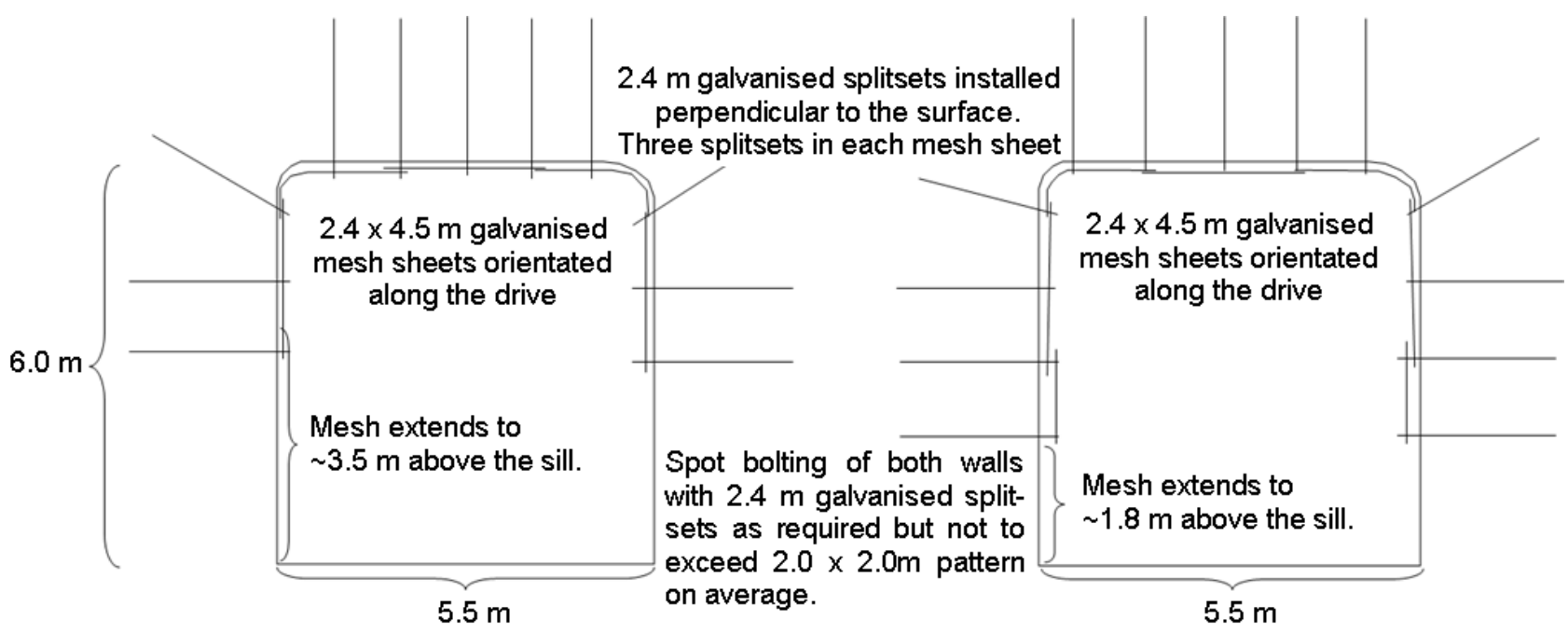

Figure 6 Example support designs in good and fair ground 


\subsection{Ground support and reinforcement system capacity}

Ground support and reinforcement designs at CGM target a FS of at least 1.5 in static conditions, with an overriding dynamic capacity in excess of $5 \mathrm{~kJ} / \mathrm{m}^{2}$. The following calculations have been used to determine whether or not the empirical design is going to be adequate from an engineering perspective for the general ground conditions observed. These calculations do not consider identifiable wedges, mafic dykes etc., which must be analysed on a case by case basis. Rather, they consider the general case of a drive in gneiss where the support is designed to manage the potential for failure relating to an arbitrary 'depth of fracture' around the rock mass/excavation interface, as a proxy for the zone encompassing the impact of blasting and stress redistribution around the opening. The determination of depth of fracture is based on the work of Faint (2010) where a survey of jumbo operators was undertaken in an endeavour to determine rock mass conditions in the backs of development. In particular, the operators were asked to estimate the depth drilled before competent ground was encountered. While extremely subjective, an average around $250 \mathrm{~mm}$ and a maximum at $375 \mathrm{~mm}$ was determined. The study was revisited and expanded by Bastian (2013), including a study of half-barrels left after blasting. This study more or less confirmed the observations of Faint (2010), with the occurrence of a slight decrease in ground conditions with depth in the mine, which was in accordance with observation.

For the purposes of empirical ground support and reinforcement, the calculations consider the worst case of Faint (2010).

On the basis of pull-testing results, a load bearing capacity of $4 \mathrm{t} / \mathrm{m}$ for a $46 \mathrm{~mm}$ split set friction anchor is considered for design purposes. Given the upper limit depth of fracture of $375 \mathrm{~mm}$ determined by Faint (2010) and a useable bolt length of $2.3 \mathrm{~m}$ allowing for a $0.1 \mathrm{~m}$ taper, a useable load capacity per $2.4 \mathrm{~m}$ split set friction anchor is determined as:

$$
\text { Load capacity per bolt }=(2.4 \mathrm{~m}-0.375 \mathrm{~m}-0.1 \mathrm{~m}) \times 4 \mathrm{t} / \mathrm{m}=7.70 \mathrm{t} / \mathrm{bolt}
$$

The required bolt density $\left(\mathrm{m}^{2} / \mathrm{bolt}\right)$ at a design FS of 1.5 and a rock mass density of $2.84 \mathrm{t} / \mathrm{m}^{3}$, for a $0.375 \mathrm{~m}$ depth of fracture is:

$$
\text { Bolt density }=7.70 \mathrm{t} / \text { bolt } /\left(1.5 \times 0.375 \mathrm{~m} \times 2.84 \mathrm{t} / \mathrm{m}^{3}\right)=4.82 \mathrm{~m}^{2} / \text { bolt }
$$

Commencing from these requirements, the ground support and reinforcement system capacities were found to be as follows.

\subsubsection{Static capacity}

The required capacity per square metre is:

$$
\text { Required capacity }=7.70 \mathrm{t} / \text { bolt } / 4.82 \mathrm{~m}^{2} / \text { bolt }=1.6 \mathrm{t} / \mathrm{m}^{2}
$$

The support system is based on the mesh size.

Bolt spacing is $1.1 \times 1.4 \mathrm{~m}$ in the worst case for a $2.4 \times 4.5 \mathrm{~m}$ mesh sheet. Thus the load capacity of the proposed support system is:

$$
\text { System capacity }=7.70 \mathrm{t} / \text { bolt } /(1.1 \mathrm{~m} \times 1.4 \mathrm{~m})=5.0 \mathrm{t} / \mathrm{m}^{2}
$$

This equates to an excess capacity in the support system at a FS of 1.5 of:

$$
5.0 \mathrm{t} / \mathrm{m}^{2}-1.6 \mathrm{t} / \mathrm{m}^{2}=3.4 \mathrm{t} / \mathrm{m}^{2}
$$

in static conditions, demonstrating that the static capacity requirements are met.

\subsubsection{Dynamic capacity}

Anecdotal reports of rock mass failure due to seismic activity have been confined to minor spitting and strain bursting. This generally equates to an energy release of $2 \mathrm{~kJ} / \mathrm{m}^{2}$ up to $10 \mathrm{~kJ} / \mathrm{m}^{2}$, depending on the 
failure mechanism (Kaiser et al. 1996). Based on recorded seismicity of up to $\mathrm{ML}_{\mathrm{L}} 1.0$ at CGM, an energy release of $5 \mathrm{~kJ} / \mathrm{m}^{2}$ for a $0.25 \mathrm{~m}$ thick slab is considered reasonable for design purposes.

The load bearing of $4 \mathrm{t} / \mathrm{m}$ for split set friction anchors is equivalent to $39.2 \mathrm{kN} / \mathrm{m}$. Kaiser et al. (1996) recommend using an ultimate displacement of up to $200 \mathrm{~mm}$ for design purposes. With an effective length of $2.3 \mathrm{~m}$ allowing for a $0.1 \mathrm{~m}$ taper, the energy absorption capacity of a $2.4 \mathrm{~m}$ split set for the ejection of slabs up to $0.25 \mathrm{~m}$ thick was determined as follows:

$$
\begin{gathered}
\text { Initial slip load }=(2.3-0.25 \mathrm{~m}) \times 39.2 \mathrm{kN} / \mathrm{m}=80.4 \mathrm{kN} \\
\text { Load after } 200 \mathrm{~mm} \text { slip }=(2.3-0.25-0.2 \mathrm{~m}) \times 39.2 \mathrm{kN} / \mathrm{m}=72.5 \mathrm{kN} \\
\text { Total energy absorbed }=0.2 \mathrm{~m} \times(72.5 \mathrm{kN}+(80.4-72.5 \mathrm{kN}) \times 0.5)=15.3 \mathrm{~kJ}
\end{gathered}
$$

The aerial coverage of the split set pattern in the worst case of a $2.4 \times 4.5 \mathrm{~m}$ mesh sheet is:

$$
\text { Aerial coverage }=1.1 \times 1.4 \mathrm{~m}=1.54 \mathrm{~m}^{2}
$$

Thus, the energy dissipation capacity of the system is:

$$
15.3 \mathrm{~kJ} / 1.54 \mathrm{~m}^{2}=9.94 \mathrm{~kJ} / \mathrm{m}^{2}
$$

This equates to an excess capacity in the support system of:

$$
9.94-5.0=4.94 \mathrm{~kJ} / \mathrm{m}^{2}
$$

Kaiser et al. (1996) state that \#4 gauge mesh such as in use at CGM has a design capacity of $5 \mathrm{~kJ} / \mathrm{m}^{2}$ with an ultimate capacity of $6-9 \mathrm{~kJ} / \mathrm{m}^{2}$, which equates to or slightly exceeds the case being considered. This simplistic analysis suggests that the ground support and reinforcement system is adequate in the dynamic conditions currently being experienced.

\section{$7 \quad$ Standard cable bolting designs}

\subsection{Lateral development arch assessment}

The lateral development arch assessment is an empirical tool for assessing the requirement for cable bolts in wide development. It can be applied where stripping of ore drives is required to pick up the full width of the ore, where parallel passing bays are developed in decline or wherever excessive width occurs, either to plan or due to overbreak. The tool dictates a cable bolt density per metre of development as follows:

$$
m=1 / 3 \rho w^{2}
$$

where:

$$
\begin{aligned}
\mathrm{m} & =\operatorname{mass}(\mathrm{t}) . \\
\rho & =\operatorname{density}\left(\mathrm{t} / \mathrm{m}^{3}\right) . \\
\mathrm{w} & =\operatorname{drive} \text { width }(\mathrm{m}) .
\end{aligned}
$$

Generally, rows of cable bolts along the axis of the development are spaced $2.0 \mathrm{~m}$ apart. Thus, the key parameter to be determined is the spacing between rings of cables across the development, at the CGM design FS of 1.5. The cable bolt ring spacing:

$$
s=(c \times n) /(m \times 1.5)
$$

where:

$\mathrm{c}=$ capacity of the cable bolt $(\mathrm{t})=40 \mathrm{t}$ for twin strand cables used at CGM, being set at the onset of inelastic yield as suggested by Hutchison and Diederichs (1996).

$\mathrm{n} \quad=$ number of rows of cables across the drive based on drive width spacing. 
The cable bolt patterns for wide development are summarised in Table 3 for an average rock mass density of $2.8 \mathrm{t} / \mathrm{m}^{3}$. Cable bolts in these patterns are not providing surface support. Rather, they are providing anchorage of the surface support system beyond the parabolic arch. A pattern of split sets appropriate to the mesh is still required. As in the case of primary ground support and reinforcement patterns, site specific design may be required in the event of unfavourable structures, wedges or dykes being present.

Table 3 Cable bolt patterns for wide development

\begin{tabular}{c|ccc}
\hline $\begin{array}{c}\text { Drive width } \\
(\mathbf{m})\end{array}$ & $\begin{array}{c}\text { Mass of parabolic } \\
\text { arch per metre } \\
(\mathbf{t})\end{array}$ & $\begin{array}{c}\text { Number of cable } \\
\text { rows }\end{array}$ & $\begin{array}{c}\text { Cable bolt } \\
\text { ring spacing } \\
(\mathbf{m})\end{array}$ \\
\hline 6 & 33.6 & 3 & 2.4 \\
7 & 45.7 & 4 & 2.3 \\
8 & 59.7 & 4 & 1.8 \\
9 & 75.6 & 5 & 1.8 \\
10 & 93.3 & 5 & 1.4 \\
11 & 112.9 & 6 & 1.4 \\
12 & 134.4 & 6 & 1.2 \\
13 & 157.7 & 7 & 1.2 \\
14 & 182.9 & 7 & 1.0 \\
\hline
\end{tabular}

\subsection{Intersection parabolic dome assessment}

Cable bolt requirements are determined through the use of the parabolic dome concept, whereby sufficient support is installed to support the mass of a dome of rock above the intersection. The area of the base of the dome is that of the largest circle which can be inscribed on the backs of the intersection. The height of the dome is determined to be one third of the diameter. The mathematics is as follows:

$$
\begin{gathered}
v=\left(\pi \times d^{3}\right) / 24 \\
m=v \times \rho \\
h=d / 3 \\
B=(m / c) \times 1.5
\end{gathered}
$$

where:

$$
\begin{aligned}
& \mathrm{v} \quad=\text { volume of the paraboloid. } \\
& \mathrm{d} \quad=\text { diameter of the paraboloid. } \\
& \mathrm{h} \quad=\text { height of paraboloid. } \\
& \mathrm{B} \quad=\text { number of cable bolts required. }
\end{aligned}
$$

In using this calculation, it is necessary to ensure that the length of the cable bolts exceeds the height of the paraboloid by a sufficient margin to provide anchorage. Hutchinson and Diederichs (1996) recommend an allowance of $2 \mathrm{~m}$ and suggest the following equation for estimating cable bolt length:

$$
\text { Length }=0.7 \times \operatorname{span}^{0.7}+2 \mathrm{~m}
$$

This methodology has been applied to the CGM standard designs using twin strand Garford bulb cable bolts on the assumption of a rock mass density of $2.8 \mathrm{t} / \mathrm{m}^{3}$ and a FS of 1.5 , as illustrated for theoretical designs in Table 4. 
Table 4 Cable bolt requirement for standard turnout and intersection designs

\begin{tabular}{|c|c|c|c|c|c|}
\hline Design & $\begin{array}{c}\text { Diameter of } \\
\text { inscribed circle }\end{array}$ & $\begin{array}{l}\text { Height of } \\
\text { paraboloid }\end{array}$ & $\begin{array}{l}\text { Minimum cable } \\
\text { bolt length }\end{array}$ & $\begin{array}{l}\text { Number of } \\
\text { cable bolts }\end{array}$ & FS limit \\
\hline $\begin{array}{l}5.0 \times 5.0 \mathrm{~m} \\
\text { Tee-intersection }\end{array}$ & 8.3 & 2.8 & 5.1 & 6 & 4 \\
\hline $\begin{array}{l}5.0 \times 5.5 \mathrm{~m} \\
\text { Tee-intersection }\end{array}$ & 8.7 & 2.9 & 5.2 & 7 & 5 \\
\hline $\begin{array}{l}5.0 \times 5.0 \mathrm{~m} \\
\text { Crossroad }\end{array}$ & 10.6 & 3.5 & 5.7 & 13 & 9 \\
\hline $\begin{array}{l}5.0 \times 5.0 \mathrm{~m} \\
\text { Elbow }\end{array}$ & 7.3 & 2.4 & 4.8 & 4 & 3 \\
\hline
\end{tabular}

\subsection{Standard cable bolt designs}

The main requirement for cable bolt reinforcement is to provide anchorage to solid ground for the mass of the parabolic dome; this remains the case unless specific wedge geometries dictate otherwise. Therefore, centralising the reinforcement around the centre of the parabolic dome provides the best overall result. Each design needs to be considered on its merits with reference to the following:

- Cables should be installed vertically. However, where necessary, cables may be offset by applying a $5^{\circ}$ inclination for each $0.5 \mathrm{~m}$ of offset required to a maximum of $15^{\circ}$.

- Standard cable bolt designs do not consider local conditions. Protocols for geotechnical assessment must be maintained with the added requirement that structural and Q-mapping be undertaken prior to excavation of the turnout or intersection with confirmatory structural mapping at completion.

- Should the geotechnical assessment determine that a standard cable bolt design is not appropriate, the location of the proposed intersection should be reviewed if possible, or the requirement for cable bolt reinforcement must be reassessed and a site specific design adopted.

- Where possible, the standard cable bolt designs allow for single pass cable bolting. This is not possible in order to achieve an adequate coverage of reinforcement in four-way intersections, and the mining of these intersections is avoided if at all possible, as a matter of good practice.

- Standard cable bolt patterns may not be valid in the vicinity of intrusive dykes and sills; appropriate site-specific design is recommended on those occasions.

An example is illustrated in Figure 7. 


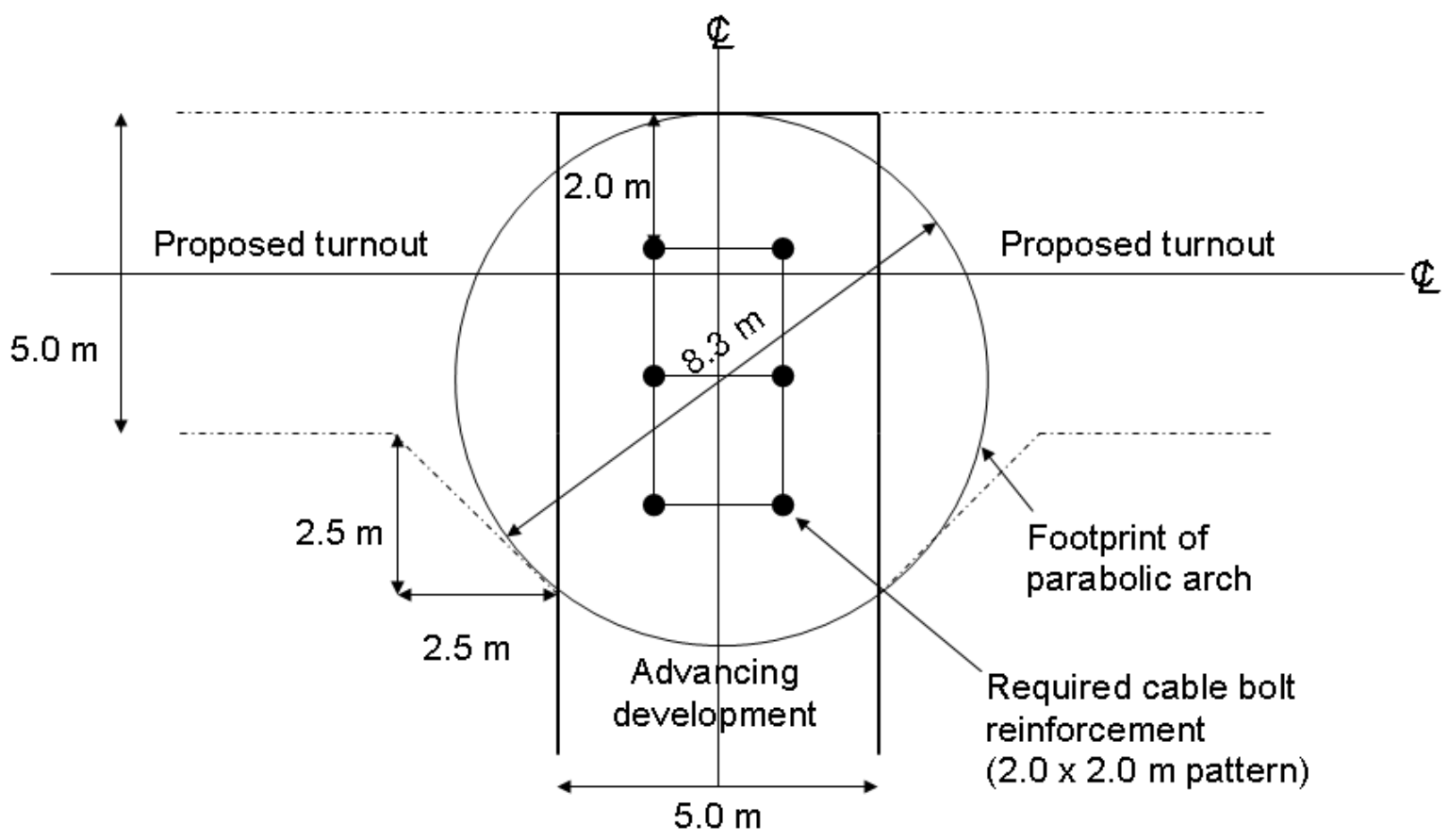

Figure 7 Standard cable bolt design for a $5.0 \mathrm{~m}$ wide Tee-intersection approaching from the leg of the Tee

\section{Conclusion}

The CGM employs a strategy of empirical design for primary and secondary ground support and reinforcement. The process employed at CGM relies on detailed geotechnical data gathering to inform the application and maintain the integrity of the empirical designs in line with documented industry experience. All designs are applied with a FS of 1.5 and the static and dynamic capability of the primary ground support and reinforcement strategies are tested against fundamental engineering principles.

Adopting the empirical design method has been a seamless transition for technical and operational staff as all data was previously being recorded anyway. Two-way communication between operators and technical staff has meant that ground support and reinforcement requirements have been adjusted as required in line with the empirical design without compromising safety for profit. The ground support and reinforcement has performed well and, despite the reduced ground support, no significant rehabilitation work has been required.

A comprehensive review of ground support and reinforcement practices after 10 years of underground mining at GCM, calling on the legacy of an extensive geotechnical database, allowed revised standards for ground support and reinforcement to be implemented using accepted principles of empirical design. The review has been formalised over the past two years with the result of efficiency and consumable cost benefits of up to 30 per cent against past practice. The process is constantly evolving and improvements in safety and economy are still being realised.

\section{Acknowledgement}

The work of the technical team at CGM over several years provided the background to allow this empirical design methodology to be implemented. 


\section{References}

Androvic, P, Bamford, P, Giles, A, Derwent, K, Kopeap, P, Hampton, S, Heydari, M, Curtis, J, Sperring, P \& Gobert, R 2013, 'Challenger Gold Mine', in WJ Rankin (ed.), Monograph 28 - Australasian mining and metallurgical operating practices, The Australasian Institute of Mining and Metallurgy, Melbourne, 3rd edn, pp. 1097-1112.

Barton, NR, Lien, R \& Lunde, J 1974, 'Engineering classification of rock masses for design of tunnel support', Rock Mechanics and Rock Engineering, vol. 6, no. 4, pp. 189-236.

Barton, NR, Løset, F, Lien, R \& Lunde, J 1980, 'Application of the Q-system in design decisions concerning dimensions and appropriate support for underground installations', in M Bergman (ed.), Proceedings of the International Symposium (Rockstore '80), Subsurface space environmental protection, low cost storage, energy savings, Pergamon Press, New York, NY, pp. 553-561.

Bastian, T 2013, Geotechnical competency investigation - backs fracturing and half-barrelling, Kingsgate Consolidated Limited, Sydney.

Deere, DU, Hendron, AJ, Patton, FD \& Cording, EJ 1967, 'Design of surface and near-surface construction in rock', in C Fairhurst (ed.), Proceedings of the 8th US Symposium on Rock Mechanics (USRMS), American Rock Mechanics Association, Minneapolis, MN, pp. 237-302.

Faint, L 2010, Backs fracturing investigation, Dominion Mining Limited, Perth.

Hutchinson, DJ \& Diederichs, MS 1996, Cablebolting in underground mines, BiTech Publishers, Richmond.

Kaiser, PK, McCreath, DR \& Tannant, DD 1996, Canadian rockburst support handbook, Geomechanics Research Centre, Sudbury, ON.

Kirsten, HAD 1983, 'The combined Q-NATM system - the design and specification of primary tunnel support', South African Tunnelling, vol. 6, no. 1, pp. 18-24.

Mining Measurement Services 2006, Challenger Gold Mine rock stress measurement 780SP, Mining Measurement Services Pty Ltd, Macclesfield.

Mining Measurement Services 2008, Challenger Gold Mine rock stress measurement jumbuck decline 580 external SP, Mining Measurement Services Pty Ltd, Macclesfield.

Mining Measurement Services 2011, Challenger Gold Mine rock stress measurement 320 DD, Mining Measurement Services Pty Ltd, Macclesfield.

Norwegian Geotechnical Institute 2013, Using the Q-system handbook: rock mass classification and support design, Norwegian Geotechnical Institute, Oslo.

Palmström, A 1982, 'The volumetric joint count - a useful and simple measure of the degree of rock jointing', Proceedings of the 4th IAEG Congress, International Association of Engineering Geology (IAEG), pp. 221-228.

Pender, EB, Hosking, AD \& Mattner, RH 1963, 'Grouted rock bolts for permanent support of major underground works', Journal of the Institution of Engineers (Australia), vol. 35, no. 7, 22 p.

Shach, R, Garshol, K \& Heltzen, A 1979, Rock bolting, a practical handbook, Pergamon Press, New York, NY.

Western Australian School of Mines 2006, Report on intact rock properties for Dominion Gold Pty Ltd - Challenger Gold Project, report, prepared for Western Australian School of Mines, Kalgoorlie. 